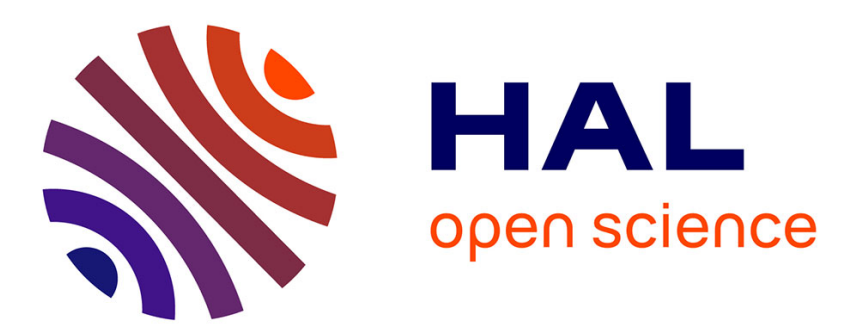

\title{
Aphids at crossroads: when branch architecture alters aphid infestation patterns in the apple tree
}

Sylvaine Simon, Karine Morel, Emilie Durand, Géraldine Brevalle, Thierry Girard, Pierre-Eric Lauri

\section{- To cite this version:}

Sylvaine Simon, Karine Morel, Emilie Durand, Géraldine Brevalle, Thierry Girard, et al.. Aphids at crossroads: when branch architecture alters aphid infestation patterns in the apple tree. Trees Structure and Function, 2012, 26 (1), pp.273-282. 10.1007/s00468-011-0629-8 . hal-01267760

\author{
HAL Id: hal-01267760 \\ https://hal.science/hal-01267760
}

Submitted on 29 May 2020

HAL is a multi-disciplinary open access archive for the deposit and dissemination of scientific research documents, whether they are published or not. The documents may come from teaching and research institutions in France or abroad, or from public or private research centers.
L'archive ouverte pluridisciplinaire HAL, est destinée au dépôt et à la diffusion de documents scientifiques de niveau recherche, publiés ou non, émanant des établissements d'enseignement et de recherche français ou étrangers, des laboratoires publics ou privés. 


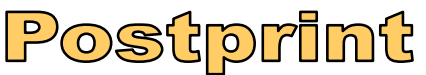

Version définitive du manuscrit publié dans / Final version of the manuscript published in : Trees, 2011, vol.26, n.1, 273-282

1 Aphids at crossroads: when branch architecture alters aphid infestation patterns in the apple

2 tree

3

4 Simon S. ${ }^{1}$, Morel K. ${ }^{1}$, Durand E. ${ }^{1}$, Brevalle G. ${ }^{1}$, Girard T. ${ }^{1}$, Lauri P.É. ${ }^{2}$

5

$6 \quad{ }^{1}$ INRA, Unité Expérimentale Recherche Intégrée UE695, Gotheron, 26320 Saint-Marcel-lès-

7 Valence, France

$8 \quad 2$ INRA, UMR AGAP, \#1334, Equipe 'Architecture et Fonctionnement des Espèces

9 Fruitières', CIRAD Lavalette, Avenue Agropolis, TA A-108/03, 34398 Montpellier Cedex 5, 10 France

Correspondence: Sylvaine Simon. Tel.: +33 (0)475.59.92.21; Fax: +33 (0)475 5886 26;

E-mail: Sylvaine.Simon@avignon.inra.fr

16 Running title: Branch architecture and aphid infestation 


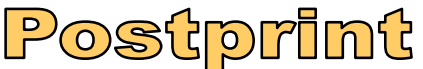

Version définitive du manuscrit publié dans / Final version of the manuscript published in : Trees, 2011, vol.26, n.1, 273-282

\section{Abstract}

1. Plant architecture highly constrains pest infestation but is rarely considered in studies on plant-insect interactions. We analysed the relationships between apple tree architectural traits manipulated by tree training and within-branch development of Dysaphis plantaginea (rosy apple aphid, RAA), a major apple pest, during its multiplication wingless phase in spring. We hypothesised that the degree of branching had an effect on RAA within-branch infestation.

2. In an experimental apple orchard, the infestation by aphid wingless forms was surveyed in two consecutive spring seasons within branches manipulated to design contrasted architectures differing in shoot numbers, shoot density and branching orders.

3. Whatever the branch management system, aphid infestation was higher on long vs. short, fruiting vs. vegetative, and growing vs. non-growing shoots. Either less infested shoots or less severe infestation were observed in the most branched system. A pattern of withinbranch short-distance infestation was confirmed. Moreover, the number of branching points between two shoots exerted a high constraint on this infestation pattern.

4. Beside possible trophic effects due to plant growth patterns already documented in the literature, a high degree of branching is likely to be a key-architectural trait to constrain within-branch aphid infestation. This opens new perspectives on the manipulation of branch architecture as a mean giving partial control of pests towards sustainable fruit production.

Key-words: branching order, Dysaphis plantaginea (rosy apple aphid), habitat complexity, infestation pattern, Malus x domestica, plant architecture 


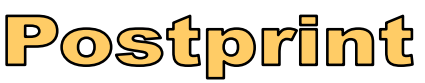

Version définitive du manuscrit publié dans / Final version of the manuscript published in : Trees, 2011, vol.26, n.1, 273-282

\section{INTRODUCTION}

Training of fruit trees is used by growers to enhance yield, fruit quality and returnbloom in orchards (Wertheim 2005a; 2005b). Tree spatial and temporal organisation, i.e. tree architecture (Bell 1991; Hallé et al. 1978), is therefore periodically modified through pruning, branch bending and selective removal of fruiting and/or vegetative shoots to distribute fruits and increase light penetration within the tree canopy (Costes et al. 2006; Lauri et al. 2004;

Lauri and Laurens 2005; Lauri et al. 2009). Because plant architecture shapes the habitat and living conditions of pests and their natural enemies (Lawton 1983; Price et al. 1980), an alteration of the population dynamics of pests is expected from tree training performed by growers. However, this latter topic is still little documented (Kührt et al. 2006; Simon et al. 2007a; Stoeckli et al. 2008a).

Some studies on the topic revealed significant effects of fruit tree architecture manipulation or aspect and height on pest and disease development (Grechi et al. 2008; Holb et al. 2001; Mani et al. 1995; Prokopy et al. 2001; Simon et al. 2006; Simon et al. 2007b; Stoeckli et al. 2008a), with favourable or unfavourable effects on infestation or infection rates, depending on the studied pest or disease. Most of these experimental studies were descriptive only. Despite proposed hypotheses to explain the observed results, mechanisms were rarely investigated in fruit trees (Simon et al. 2007a). Literature on other plant models (e.g. Pistacia, Martinez and Wool 2003; Cotton, Anderson and Agrell 2005; Birch, Riihimäki et al. 2006) can help identifying the underlying processes which include growth patterns: plant sectoriality (Araújo et al. 2006; Larson and Whitham 1997; Marquis 1996; Orians and Jones 2001), habitat complexity (Finke and Denno 2006; Langellotto and Denno 2004; Lawton 1983) and connectivity (Hanan et al. 2002; Skirvin and Fenlon 2003). In apple, which is one of the most documented fruit tree production, effects of tree architecture were reported on codling moth, Cydia pomonella (L.) (Lepidoptera: Tortricidae), (Simon et al. 2007b; 
Version définitive du manuscrit publié dans / Final version of the manuscript published in : Trees, 2011, vol.26, n.1, 273-282

Stoeckli et al. 2008a) and the rosy apple aphid (RAA), Dysaphis plantaginea (Passerini)

(Hemiptera: Aphididae) (Simon et al. 2006). Both are major pests of apple trees, which may cause serious damages to fruits (codling moth), shoots, fruits and branches (RAA;

Bonnemaison 1959; Deberardinis et al. 1994). These pests require pesticide use to be kept under control. Hypotheses to explain results were related to microclimate and fruit phenology for the flying pest, i.e. the codling moth, (Stoeckli et al. 2008a) and within-branch shoot distribution in spring for the walking wingless RAA pest (Simon et al. 2006). Indeed, RAA winter eggs laid in autumn by aphids re-emigrating on their primary host, the apple tree, hatch around March in the area, and stem mothers infest buds before bloom. During a parthenogenesis phase, primary and then secondary colonies develop on trees and cause damage, mainly through severe leaf curling during fruit and shoot growth in spring (Bonnemaison 1959). At this time, because winged forms are not present before infestation peak and/or fly away from apple towards their secondary host-plant Plantago spp. (Plantaginaceae) (Bonnemaison 1959), founders of new colonies within the branches are mainly 'pedestrians' which can be seen walking on the branch axes. Branch architecture, as defined by structural and growth traits, is expected to constrain the RAA's movement patterns in its walking behaviour.

Here we aim to identify some of the architectural parameters affecting RAA withintree development in spring before it flies to its secondary host. The approach is based on the study of RAA development within branches belonging to the same apple cultivar but with two pruning strategies to design contrasted branch architectures. The two experimented branch managements belonging to known tree training systems are first presented and their effects on branch architecture assessed. Then architectural parameters of both branch managements are analysed for their effects on RAA development. Our main hypothesis was that the degree of branching is a relevant architectural trait to alter RAA movement in its dissemination phase in 


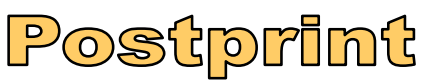

Version définitive du manuscrit publié dans / Final version of the manuscript published in: Trees, 2011, vol.26, n.1, 273-282

spring when walking from one leafy shoot to another. Lastly, the potential of tree architecture manipulation as a method giving partial control of orchard pests is discussed.

\section{MATERIALS AND METHODS}

The study was carried out in May 2007 and 2008 at the INRA (National Institute for Agricultural Research) Gotheron experimental unit in South-East France (4458'33" North, $4^{\circ} 55^{\prime} 45^{\prime \prime}$ East). Located in the middle Rhône Valley, the area has a continental climate with summer Mediterranean influences. The soil in the area has a sandy-loam shallow and stony structure derived from old washed out sediments of the Rhône river.

\section{Experimental orchard and tree training systems}

The experimental orchard was planted in 2001 with cv. 'Pitchounette' (INFEL ${ }^{\circledR}$ 3318), a scab $V f$-resistant cultivar, grafted onto M9, which is moderately susceptible to RAA (Parveaud et al. 2010). One tree out of ten was a pollinator tree. Tree density was 1110 trees.ha ${ }^{-1}$ with $4.5 \mathrm{~m}$ between-row and $2 \mathrm{~m}$ within-row planting distances. Each of the eight North-South oriented rows of the orchard included 15 trees. All trees had a similar pest and disease management, watering, fertilising, within-row chemical weeding and grass mowing in the orchard alleys. During the first four years after planting, i.e. from 2001 to 2004, all trees were trained to the original solaxe system (OS; Lauri and Lespinasse 2000; Willaume et al. 2004). In brief, the OS system is based on three main rules: a vertical trunk up to $2.5 \mathrm{~m}$ or more, a regular distribution of 10 to 15 main branches, i.e. issued from the trunk, on average along and around the trunk from 1m onwards (branches in excess are completely removed) and the bending below the horizontal of all branches. There was no pruning within each individual branch, except the removal of vigorous shoots ('water shoots') which may appear on the bent portions of branches and trunk. In 2005, four blocks of two contiguous rows were 


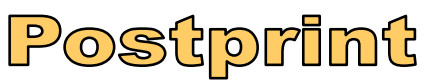

Version définitive du manuscrit publié dans / Final version of the manuscript published in : Trees, 2011, vol.26, n.1, 273-282

115 designed and each row within a block was assigned at random to one of the following training 116 systems:

117 (i) Original solaxe as in previous years,

\section{Description of branch architecture}


Version définitive du manuscrit publié dans / Final version of the manuscript published in : Trees, 2011, vol.26, n.1, 273-282

Branch architecture was described by recording the position of each current-year shoot on which RAA could potentially develop within the branch (Fig. 1). More precisely, two concepts were used in our recording: branching order and rank of insertion on the main axis of the branch.

- The branching order of a current-year shoot is the number of branching points between the main axis of the branch and this shoot. Namely, the main axis of the branch has a branching order of 0 , a sub-branch inserted on the main axis has a branching order of 1 , a sub-branch inserted on a 'order 1'-sub-branch has a branching order of 2, etc.

- The rank of insertion numbers each shoot along the main axis of the parent branch from the proximal, i.e. near the trunk, to the distal parts of the branch. Each current-year shoot is then characterised by a list of numbers giving the rank of insertion of each intermediate sub-branch between the main axis of the branch and this shoot. For example, a current-year shoot numbered ' $5-1$ ' is the first shoot inserted on the fifth sub-branch inserted on the main axis of the branch when counting from the proximal part of the branch (Fig. 1). This description permitted identification of the topological proximity of shoots and recording of the number of branching points between the apices of two adjacent shoots. As an example, on Figure 1, the two nearest (adjacent) neighbour shoots of '1-2' shoot (order 2) are '1-1-1' (order 3) and '1-3' (order 2) in proximal and distal topological positions, respectively, and the number of branching points that a walking aphid would meet from the apex of ' $1-1-1$ ' shoot to ' $1-2$ ' apex is 3. In parallel to its topological position, each shoot was described and assigned to the following groups: length category (short, $<5 \mathrm{~cm}$; long, $\geq 5 \mathrm{~cm}$ ), growing status (yes/no, i.e. presence of newly emitted leaves or not if growth has stopped), and reproductive status (yes/no).

\section{Pest management and assessment of the RAA development}


Version définitive du manuscrit publié dans / Final version of the manuscript published in : Trees, 2011, vol.26, n.1, 273-282

RAA control consisting of one mineral oil and one acetamiprid applied before bloom was required in all systems to permit tree growth and preserve orchard longevity. Other compounds applied during the period of aphid assessments were thinning products:

Naphthaleneacetamide (NAD), Naphthaleneacetic acid (NAA) and carbaryl (also being classified as insecticide) in 2007; NAD alone in 2008.

The infestation dynamics were described on the 8 selected branches per training system at two consecutive dates after petal fall: at the beginning of RAA multiplication and dissemination phase in spring (D1) and at RAA infestation peak (D2), i.e. 10 to 12 days after the first assessment date depending on the year. Because the studied branches were isolated and selected on trees with no other symptoms (see Materials and methods, section 1), the observed infestation events could be considered to be mainly due to RAA within-branch movements. As 2008 assessments started at the very beginning of RAA dissemination phase, initial infestation levels were lower in 2008 than in 2007. Because infestation was naturally occurring in the orchard, trees and branches that were assessed were different in 2007 and 2008. For each one-year shoot within a branch, RAA population was assigned into four infestation classes: 0 , no aphids; 1 , only individual aphids and no progeny; 2 , small colony, i.e. restricted to 1 or 2 leaves; 3 , large colony, spreading over 3 leaves or more. The infestation severity of each branch was the mean infestation class of all shoots on that branch. The percentage of RAA-infested shoots of each branch was also calculated. All other aphids, mainly the Aphis spp. complex (Aphis pomi de Geer, A. spiraecola Patch) (Aphididae) were recorded by a presence/absence index. However, as infestation levels by Aphis spp. were very low and similar whatever the date and the training system (infestation peaked at $4.2 \%$ infested shoots in 2007 and $1.7 \%$ in 2008), only RAA infestation was considered in the present analysis. As natural enemies of RAA were very scarce (pers. obs.) at the time of aphid 


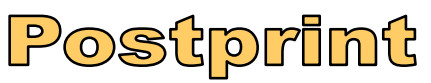

Version définitive du manuscrit publié dans / Final version of the manuscript published in: Trees, 2011, vol.26, n.1, 273-282 assessment, their effect on RAA development was considered to be null or very low in the present study.

\section{Data analysis}

The effect of the training system, our main studied factor, on (i) the branch architectural traits and (ii) RAA infestation, was investigated through successive steps involving in each case a different set of variables.

A first step of the analysis considered each branch as a repetition. An ANOVA (studied factor: tree training; block factor) was carried out on the four following architectural and infestation variables: the number of shoots per branch, shoot density (total number of currentyear shoots of a branch per unit of length of the main axis of this branch, number of shoots.m $\left.{ }^{1}\right)$, RAA infestation level (\% infested shoots) and mean severity of the branch. Percentage data were arcsin-transformed before ANOVA. The general conditions of parametric ANOVA (i.e. normal distribution and independence of residuals, homoscedasticity) were checked from the graph of the residuals plotted against the predicted values and Shapiro-Wilks test (Dagnélie 1975). A second step in the analysis considered the current-year shoots as elementary units. A $\chi^{2}$ test was used to analyse the distribution of shoots pooled per training system (CT/OS) in the three following analyses: combined shoot descriptive categories (length $\mathrm{x}$ reproductive status x growth status), yielding to different degrees of freedom since not all combinations existed; branching orders and infestation course patterns between D1 and D2. Independently of the training system (shoots pooled whatever the training system), a $\chi^{2}$ test was also used to analyse if infestation was similar (in proportion) between the two status of each descriptor considered separately, e.g. were short vs. long shoots similarly infested? Statistical analysis was done with Statgraphics software (Statistical graphics Corp., Rockville, MD, USA). 
Version définitive du manuscrit publié dans / Final version of the manuscript published in : Trees, 2011, vol.26, n.1, 273-282

A regression analysis was used to analyse the short-distance infestation pattern of RAA within the branch. To do so, the RAA infestation severity class of a given shoot (target shoot) at date 2 (dependent variable at D2) was plotted against the mean infestation severity class of its nearest adjacent shoots at date 1 (independent variable at D1). These adjacent shoots were those inserted immediately in proximal and distal topological position (see Materials and methods, Section 2) of this given shoot; two shoots (general case) or only one shoot (no distal adjacent shoot in the case of apices, no proximal adjacent shoot for the nearest of the tree trunk) were thus considered. Because shoot numbers within the different infestation classes were too low to develop this analysis at branch level, calculations were made per training system. The mean infestation class at D2 (Y-axis) was computed per training system for each group of target shoots (when three or more shoots) having the same mean infestation class of their adjacent shoots at D1 (X-axis).

To test our hypothesis of an effect of the number of branching points (independent variable) on RAA infestation within the branch (dependent variable), the infestation severity class of a given shoot at D2 was plotted against the infestation severity class of its proximal shoot at D1 considering the number of branching points between these paired shoots. In our topological description, considering only the proximal (and not distal) adjacent shoot was supported by the fact that apices of any current-year shoot (e.g. shoot ' 1 ' on Fig. 1) had no distal shoot which would lead to exclude up to 376 shoots from this regression analysis in 2007. As our aim was to highlight a possible effect of branching per se on RAA withinbranch development (i.e. independently of the training system), this analysis was carried out on the pooled data of the 16 study branches. The mean infestation class was computed at D2 (Y-axis) for each group of target shoots (when three or more shoots) whose proximal shoots had the same infestation class at D1 (X-axis) in the case of 1, 2, etc. branching points between the considered paired shoots. 


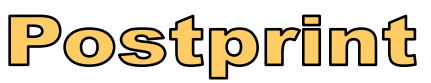

Version définitive du manuscrit publié dans / Final version of the manuscript published in : Trees, 2011, vol.26, n.1, 273-282

These latter two regression analyses were done using the Ordinary Least Square (OLS) regression method which is appropriate for fitting bivariate lines in allometry with the hypothesis of a predictive relationship between the independent variable, here in the $\mathrm{X}$-axis, and the dependent variable, here in the Y-axis (SMATR software, Falster et al. 2006; Warton et al. 2006). Comparisons between regression lines were carried out following two steps.

First, slopes of all lines were compared to determine if there was a common slope, i.e. a same scaling coefficient, among groups. Second, in the case slopes did not change across groups, tests for shift in elevation (intercept, i.e. allometric constant) and shift along the common axis were computed.

\section{RESULTS}

\section{Architectural traits shaped by branch manipulation}

In 2007, 2030 shoots from 8 OS branches (1104 shoots) and 8 CT branches (926 shoots), were assessed (Table 1). In 2008, 3470 shoots from 8 OS branches (1282 shoots) and 8 CT branches (2188 shoots) were surveyed (Table 1). There were significant differences between training systems for the proportion of shoots within combined categories of descriptors whenever existing (short/long x growing/stopped x fruiting/vegetative). More precisely, in 2007, higher proportions of fruiting shoots (including long growing and short shoots) together with a lower proportion of short vegetative stopped shoots were observed in the OS compared to the CT system $\left(\chi^{2}=266.73,6\right.$ d.f., $\left.P<0.001\right)$. In 2008 , the proportion of vegetative growing shoots was higher in OS compared to CT branches $\left(\chi^{2}=82.43,5\right.$ d.f., $\left.P<0.001\right)$. Higher proportions of growing shoots with (2007) or without (2008) fruits were thus observed in OS compared to CT branches. The number of shoots per branch (Table 1) was significantly higher in CT than OS branches in 2008 (ANOVA, $\mathrm{F}_{1,8}=11.02, P<0.05$ ). Shoot density (Table 1) was also higher in CT compared to OS trees in 2008 (ANOVA, $\mathrm{F}_{1,8}=22.67, P<$ 


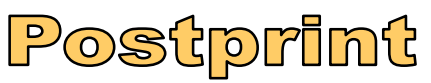

Version définitive du manuscrit publié dans / Final version of the manuscript published in : Trees, 2011, vol.26, n.1, 273-282

0.01 ). There was no significant difference between training systems (ANOVA, $P>0.05$ ) in 2007 for these two architectural variables and no block effect in any year.

The distribution of shoots according to their branching order (Fig. 2a, b) displayed strong differences between training systems in both years (2007, order 3 and 4 shoots pooled: $\chi^{2}=$ 244.43, 2 d.f., $P<0.001 ; 2008: \chi^{2}=337.52,3$ d.f., $\left.P<0.001\right)$. Apart from the training system, the proportion of shoots in the highest orders was higher in 2008 compared to 2007 (Fig. 2a,

b) attesting to the increased branching process which accompanies branch ageing between the two years. But the proportion of shoots in branching orders 3 and 4 was higher in CT than in OS branches in both years.

\section{Effect of the training system on shoot infestation by RAA}

2.1. RAA infestation and severity at branch level

The percentage of RAA-infested shoots and severity (Table 2) increased between the

two assessment dates (D1, D2) in both years. In 2007, large variations were observed between branches within the same training system: RAA infestation rate at D1 was between $2.6 \%$ and 67.7\% infested shoots in OS branches, and between $1.3 \%$ and $80.4 \%$ in CT branches. In 2008, the infestation at D1 was at its beginning and the assessed branches were more homogeneously infested with $0.4 \%$ to $4.7 \%$ infested shoots in CT and $0.4 \%$ to $10.0 \%$ infested shoots in OS branches. Because of this high intra-training system variability, no significant difference between training systems was displayed whatever the infestation variable (i.e. percent infested shoots or severity) in any study year (ANOVA, $P>0.05$ ). No significant block effect or interaction block-training system could be displayed either. 
Version définitive du manuscrit publié dans / Final version of the manuscript published in : Trees, 2011, vol.26, n.1, 273-282

Although at a given date no differences in infestation were displayed between training

systems in both study years, infestation courses of shoots between D1 and D2 were

significantly different between training systems in 2007 (Fig. 3a). Especially the proportion of newly infested shoots between D1 and D2 assessment dates ("Peak only") was higher in OS

than in CT branches $\left(\chi^{2}=25.07,3\right.$ d.f., $\left.P<0.001\right)$ : $28.4 \%$ vs. $20.8 \%$ shoots get infested

between D1 and D2 in the CT and OS systems, respectively. However in 2008 (Fig. 3b), with

less infestation, the infestation courses were similar for both training systems: $77.0 \%$ of the

became infested between D1 and D2.

2.3. RAA infestation according to the shoot category

Whatever the training system, RAA infestation was higher on long vs. short shoots, on growth status: $\left.\chi^{2}=28.79, P<0.001\right)$.

304

\section{Effect of tree training on RAA short-distance infestation within branches}

The relation between the infestation severity of a given shoot at D2 and the infestation severity of its adjacent shoots at D1 (Fig. 4a, b) attested to short-distance patterns of RAA infestation along the branch in both years whatever the training system: the infestation of a shoot was all the more severe at D2 if adjacent shoots were severely infested at D1. This relationship generally fitted with a linear regression of same slope for the two training 


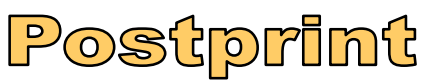

Version définitive du manuscrit publié dans / Final version of the manuscript published in: Trees, 2011, vol.26, n.1, 273-282

systems in 2007 and $2008(P>0.05)$. Whereas there was no significant difference between intercepts of OS and CT branches in 2007, OS branches had a higher intercept than CT branches in 2008 (Wald statistic $=3.966, P<0.05$ ). This latter result indicated that whatever the infestation severity of adjacent shoots at D1, the infestation severity of the target shoot at D2 was higher in OS than in CT branches. This held true whatever the infestation severity of the target shoot at D1.

In 2007 the infestation severity at D2 of a given shoot according to the infestation severity of its proximal adjacent shoot at D1 was dependent upon the number of branching points decreasing between the ' 1 branching point' and ' 4 branching points' cases (Fig. 5; significant difference in slopes, likelihood ratio statistic $=3.069, P<0.05$ ). The low infestation level at D1 in 2008 did not permit a similar analysis.

\section{DISCUSSION}

\section{1) Tree training affects RAA infestation through its effects on branch architecture}

Aphid infestation dynamics were affected by branch architecture modulated by tree training. A strong effect of extinction pruning was displayed on: (i) shoot proportions in descriptive categories (length, and growth and reproductive status); and (ii) within-branch shoot architecture. The extinction pruning procedure decreased the number of shoots in a given year but provoked an increase in the number of shoots of higher branching order on the remaining laterals in the following years. This led to an increase in shoot density, i.e. the number of shoots per unit of length of the main branch axis. Such effect is not directly aimed but induced by the extinction procedure. It has not been previously described and has to be differentiated from the known effect of winter heading cut (Barritt 1992) which reduces the length of current season- and one-year-old wood and stimulates the growth of new long shoots (e.g. Grechi et al. 2008). 
Version définitive du manuscrit publié dans / Final version of the manuscript published in : Trees, 2011, vol.26, n.1, 273-282

Superimposed to aggregation (Lathrop, 1928), a strong structuring effect of

architecture through the number of branching points between 2 shoots was observed on the dispersal of individuals to colonize new shoots. Within-branch RAA infestation dynamics

relied on two superposed processes: within-branch aphid dissemination and/or multiplication

rates, which were likely to prevail since only wingless RAA forms were present along the

experiment in (at least partly) isolated branches. Moreover, as all training practices were

similar in both training systems and no or scarce competitors (other aphids) or regulators

(natural enemies) were observed, differences in aphid infestation were only due to the

intrinsic properties of the branch architecture shaped by the training system. We investigated

two infestation processes under natural and not controlled infestation conditions for different

levels of initial RAA infestation: (i) short-distance dissemination according to branching in

2007 when a wide range of infestation levels occurred (Fig. 5), and (ii) short-distance

infestation patterns according to the training system, under a low infestation background

(2008, Fig. 4b). These differences in initial infestation can explain different infestation differed in OS and CT branches in 2007 (Fig. 3a) for a similar severity increase (Fig. 4a). The opposite was observed in 2008: the proportion of infested shoots was similar (Fig. 3b), but severity differed (Fig. 4b). We may hypothesise that at least two interacting processes occurred:

(i) The resource hypothesis: less propitious feeding resources, e.g. related to leaf nitrogen content as well as a lower proportion of shoots suitable for aphid development (Grechi et al. 2010) induce a lower multiplication rate of aphids. The highest infestation of long growing and fruiting shoots of our study is also related to well-known trophic relationships. This result is consistent with the preferential development of fruit tree aphids on growing shoots (Grechi et al. 2008) and more especially when they are long (Stoeckli et al. 2008b) in the peach - 
Version définitive du manuscrit publié dans / Final version of the manuscript published in : Trees, 2011, vol.26, n.1, 273-282

361

362

Myzus persicae (Sulzer) (Aphididae) and apple - A. pomi cases studies, respectively. Sap

nutrient quality mediated by source-sink processes (also altered by sap-consumer aphids) can explain such prevalence of aphids on growing and/or fruiting shoots (Larson and Whitham 1997). This resource hypothesis, which was not directly investigated in the present study, is documented in literature.

(ii) The structural hypothesis: the dispersal process is constrained by both a higher degree of branching and a higher shoot density. Such constrain may explain both a lower proportion of newly infested shoots (2007, Fig. 3a) and a less severe RAA infestation at D2 (2008, Fig. 4b) in CT compared to OS branches because of a delayed arrival of aphids on the newly infested shoots. This hypothesis is supported by a lower infestation progress when aphid pathway from one shoot to its distal neighbour had 4 compared to 1 branching points (Fig. 5). To the best of our knowledge, as there is no previous study establishing differences in trophic resources related to the degree of branching in a fruit tree (see Fig. 5, drawn independently of the training system), the structural hypothesis warrants further comments.

\section{2) Insect movement in complex habitats and applications for aphid control}

In the structural hypothesis, each branching point can be seen as a node from a geometrical point of view but as a crossroads for pedestrian foraging aphids. The number of crossroads related to the branching degree affects the probability of reaching the target resource, i.e. whether next or a more distant shoot (Neuvonen 1999). At 0.5 probability for each direction at a crossroads, successive crossroads along the aphid pathway will then result in a very low probability of reaching a topologically distant shoot, without counting increased travel time due to unsuccessful forward and backward movements along the branch. Patterns of connectivity (Hannunen 2002; Randlkofer et al. 2010) seen as the measure of physical contacts between shoots may also interfere although not under focus in our study. The theory 
Version définitive du manuscrit publié dans / Final version of the manuscript published in : Trees, 2011, vol.26, n.1, 273-282

of dendritic networks applied to population dynamics (Campbell Grant et al. 2007) may help

to represent the within-branch movement and colonisation of aphids, and the significance of shoots, sub-branches and crossroads (nodes). Branches may be seen as composed of suitable habitats (shoots) and pathways of dispersal (main axes and axes of sub-branches) that may present more or fewer crossroads according to the degree of branching. This also comes back to plant heterogeneity and sectoriality (Orians and Jones 2001) as underlying processes constraining aphid population dynamics within apple tree branches. This opens a field of research to investigate these mechanisms via the study of within-tree 3D topology and geometry (structural aspect) and nutritional status (physiological aspect) of shoots in relation to branch architecture and RAA infestation rates.

At orchard level, tree architectural traits are both genetically determined for the general tree habit (Lespinasse and Delort 1986; Lauri and Laurens 2005; Costes et al 2006) and manipulated by cultural practices, namely tree training and pruning (Lauri 2002). Tree architecture manipulation can contribute to modify (i) resource availability and access (plantmediated 'bottom up' processes) and (ii) natural enemies' attractiveness and success in prey localisation (natural enemies-mediated 'top down' processes). Natural enemies were not active in the present study, most probably because of their late arrival. But when considering the complete apple pest complex, another important step would include tri-trophic interactions among plant, pests and natural enemies. It has also to be considered that natural enemies may be less efficient in complex habitats (Gingras and Boivin 2002; Legrand and Barbosa 2003; Randlkofer et al. 2010; Riihimäki et al. 2006) despite increased abundance (Langellotto and Denno 2004). Previous studies have demonstrated the benefits of CT for yield and fruit quality (Lauri et al. 2007) and to lower aphid damage on apples (Simon et al. 2006). Although expected benefits of tree training to control RAA are partial only, tree training appears to be a relevant lever to consider and to combine with other protection methods. The identification of 


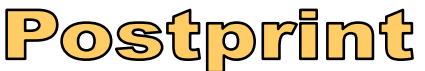

Version définitive du manuscrit publié dans / Final version of the manuscript published in: Trees, 2011, vol.26, n.1, 273-282

architectural traits detrimental to pests thus contributes to design scientifically-based tree training systems to decrease pesticide dependence in orchards and to contribute to sustainable fruit production.

\section{Acknowledgements}

This work was supported by the French Ministry of Agriculture (C06-01- Pommiers;

Programme 142 - 27, Ctps 2007-2009). We are grateful to the staff members of Gotheron experimental unit and B. Hucbourg (GRCETA Basse-Durance) for their contribution to tree training and orchard management, to J.L. Hemptinne (ENFA Toulouse) and J.L. Regnard (Supagro Montpellier) for stimulating discussions, and to David Biron for his helpful advice on the English version.

\section{References}

Anderson P, Agrell J (2005) Within-plant variation in induced defence in developing leaves of cotton plants. Oecologia 144:427-434

Araújo APA, de Paula JD, Carneiro MAA, Schoereder JH (2006) Effects of host plant architecture on colonization by galling insects. Austral Ecol 31:343-348

Barritt BH (1992) Intensive orchard management. Good Fruit Grower, Washington State Fruit Commission, Yakima, Washington

Bell A (1991) Plant form—an illustrated guide to flowering plant morphology. Oxford University Press, Oxford

Bonnemaison L (1959) Le puceron cendré du pommier (Dysaphis plantaginea Pass.) Morphologie et biologie - Méthodes de lutte. Ann Epiphyt 10:257-322

Campbell Grant EH, Lowe WH, Fagan WF (2007) Living in the branches: population dynamics and ecological processes in dendritic networks. Ecol Lett 10:165-175 


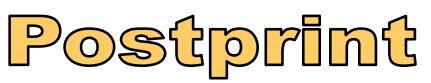

Version définitive du manuscrit publié dans / Final version of the manuscript published in: Trees, 2011, vol.26, n.1, 273-282

Costes E, Lauri PÉ, Regnard JL (2006) Analysing fruit tree architecture. Implication for tree management and fruit production. Hortic Rev 32:1-61

Dagnélie P (1975) Théorie et méthodes statistiques, Volume 2. Les Presses Agronomiques de Gembloux, Gembloux

Deberardinis E, Baronio P, Baumgartner J (1994) The effect of aphid (Dysaphis plantaginea Pass, Hom, Aphididae) feeding on apple fruit-growth. Ecol Model 72:115-127

Falster DS, Warton DI, Wright IJ (2006) User's guide to SMATR: Standardised Major Axis Tests \& Routines. Version 2.0. Homepage: http://www.bio.mq.edu.au/ecology/SMATR/

Finke DL, Denno RF (2006) Spatial refuge from intraguild predation: Implications for prey suppression and trophic cascades. Oecologia 149:265-275

Gingras D, Boivin G (2002) Effect of plant structure, host density and foraging duration on host finding by Trichogramma evanescens (Hymenoptera: Trichogrammatidae). Environ Entomol 31:1153-1157

Grechi I, Sauge MH, Sauphanor B, Hilgert N, Senoussi R, Lescourret F (2008) How does winter pruning affect peach tree - Myzus persicae interactions? Entomol Exp Appl $128: 369-379$

Hallé F, Oldeman RAA, Tomlinson PB (1978) Tropical Trees and Forests. Springer-Verlag, Berlin

Hanan J, Prunsinkiewicz P, Zalucki M, Skirvin D (2002) Simulation of insect movement with respect to plant architecture and morphogenesis. Comput Electron Agric 35:255-269

Hannunen S (2002) Vegetation architecture and redistribution of insects moving on the plant surface. Ecol Model 155:149-157

Holb IJ, Gonda I, Bitskey K (2001) Pruning and incidences of diseases and pests in environmentally oriented apple growing systems: some aspects. Int J Hortic Sci 7:24-29 


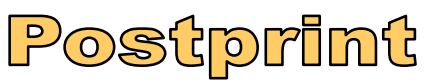

Version définitive du manuscrit publié dans / Final version of the manuscript published in: Trees, 2011, vol.26, n.1, 273-282

Kührt U, Samietz J, Dorn S (2006) Effect of plant architecture and hail nets on temperature of codling moth habitats in apple orchards. Entomol Exp Appl 118:245-259

Langellotto GA, Denno RF (2004) Responses of invertebrate natural enemies to complexstructured habitats: a meta-analytical synthesis. Oecologia 139:1-10

Larson KC, Whitham TG (1997) Competition between gall aphids and natural plant sinks: plant architecture affects resistance to galling. Oecologia 109:575-582

Lathrop FH (1928) The biology of apple aphids. Ohio J Sci 28(4): 177-204

Lauri PÉ, Lespinasse JM (2000) The Vertical Axis and Solaxe systems in France. Acta Hortic $513: 287-296$

Lauri PÉ (2002) From tree architecture to tree training - An overview of recent concepts developed in apple in France. Journal of the Korean Society for Horticultural Science 43(6):782-788

Lauri PÉ, Willaume M, Larrive G, Lespinasse JM (2004) The concept of centrifugal training in apple aimed at optimizing the relationship between growth and fruiting. Acta Hortic $636: 35-42$

Lauri PÉ, Laurens F (2005) Architectural types in apple (Malus X domestica Borkh.). In: Dris R (ed) Crops: Growth, Quality and Biotechnology. World Food Ltd., Helsinki, pp 13001314

Lauri PÉ, Crété X, Ferré G (2007) Centrifugal training in apple - Appraisal of a two-year experiment on cv. 'Galaxy' in southeast France. Acta Hortic 732:391-396

Lauri PÉ (2009) Developing a new paradigm for apple training. Compact Fruit Tree 42: 17-19

Lauri PÉ, Costes E, Regnard JL, Brun L, Simon S, Monney P, Sinoquet H (2009) Does knowledge on fruit tree architecture and its implications for orchard management improve horticultural sustainability? An overview of recent advances in the apple. Acta Hortic $817: 243-249$ 


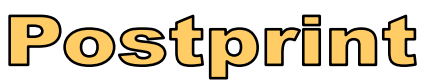

Version définitive du manuscrit publié dans / Final version of the manuscript published in : Trees, 2011, vol.26, n.1, 273-282

Lawton JH (1983) Plant architecture and the diversity of phytophagous insects. Annu Rev Entomol 28:23-39.

Legrand A, Barbosa P (2003) Plant morphological complexity impacts foraging efficiency of adult Coccinella septempunctata L. (Coleoptera: Coccinellidae). Environ Entomol 32:1219-1226

Lespinasse JM, Delort F (1986) Apple tree management in vertical axis: appraisal after ten years of experiment. Acta Hortic 160:120-155

Mani E, Wildbolz T, Riggenbach W (1995) Effect of pheromone trap position in large and small trees and in the open field on the catch of codling moth, Cydia pomonella, males. Mitt Schweiz Entomol Ges 68:69-78

Marquis RJ (1996) Plant architecture, sectoriality and plant tolerance to herbivores. Vegetatio $127: 85-97$

Martinez JJY, Wool D (2003) Differential response of trees and shrubs to browsing and pruning: the effects on Pistacia growth and gall-inducing aphids. Plant Ecol 169:285-294

Neuvonen S (1999) Random foraging by herbivores: complex patterns may be due to plant architecture. J Ecol 87:526-528

Orians CM, Jones CG (2001) Plants as resource mosaics: a functional model for predicting patterns of within-plant resource heterogeneity to consumers based on vascular architecture and local environmental variability. Oikos 94:493-504

Parveaud CE, Gomez C, Libourel G, et al. (2010) Assessment of the susceptibility to pests and diseases of 36 apple cultivars in four low-input organic orchards in France. Proceedings Ecofruit $14^{\text {th }}$ International Conference on Organic Fruit-Growing, Hohenheim, 22-24 February 2010 (ed. by IFOAM EU group). http://www.ecofruit.net/proceedings-2010.html (accessed on 21 April 2011) 


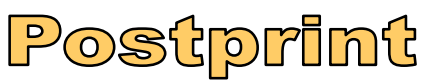

Version définitive du manuscrit publié dans / Final version of the manuscript published in : Trees, 2011, vol.26, n.1, 273-282

509 Price PW, Bouton CE, Gross P, McPheron BA, Thompson JN, Weis AE (1980) Interactions among three trophic levels: influence of plants on interactions between insect herbivores and natural enemies. Annu Rev Ecol Syst 11:41-65

Prokopy RJ, Wright SE, Black JL, Rull J (2001) Size of orchard trees as a factor affecting 125:371-375

Randlkofer B, Obermaier E, Casas J, Meiners T (2010) Connectivity counts: disentangling effects of vegetation structure elements on the searching movement of a parasitoid. Ecol Entomol 35:446-455

Riihimäki J, Vehviläinen H, Kaitaniemi P, Koricheva J (2006) Host tree architecture mediates the effect of predators on herbivore survival. Ecol Entomol 31:227-235

Simon S, Lauri PÉ, Brun L, Defrance H, Sauphanor B (2006) Does manipulation of fruit-tree architecture affect the development of pests and pathogens? A case study in an organic apple orchard. J Hortic Sci Biotechnol 81:765-773

Simon S, Sauphanor B, Lauri PE (2007a) Control of fruit tree pests through manipulation of tree architecture. Pest Technol 1:33-37

Simon S, Miranda C, Brun L, Defrance H, Lauri PÉ, Sauphanor B (2007b) Effect of centrifugal tree training on pests and pathogens in apple orchards. IOBC/WPRS Bull $30: 237-245$

Skirvin DJ, Fenlon J (2003) Of mites and movement: the effects of plant connectness and temperature on movement of Phytoseiulus persimilis. Biol Control 27:242-250

Stoeckli S, Mody K, Dorn S (2008a) Influence of canopy aspect and height on codling moth (Lepidoptera: Tortricidae) larval infestation in apple, and relationship between infestation and fruit size. J Econ Entomol 101:81-89 


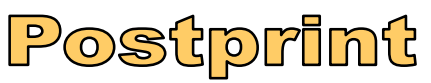

Version définitive du manuscrit publié dans / Final version of the manuscript published in : Trees, 2011, vol.26, n.1, 273-282

533 Stoeckli S, Mody K, Dorn S (2008b) Aphis pomi (Hemiptera: Aphididae) population 534 development, shoot characteristics, and antibiosis resistance in different apple genotypes. J $535 \quad$ Econ Entomol 101:1341-1348

536 Warton DI, Wright IJ, Falster DS, Westoby M (2006) Bivariate line-fitting methods for $537 \quad$ allometry. Biol Rev 81:259-291

538 Wertheim SJ (2005a) Pruning. In: Tromp J, Webster AD, Wertheim SJ (eds) Fundamentals of 539 Temperate Zone Tree Fruit Production. Backhuys Publishers, Leiden, pp 176-189

540 Wertheim SJ (2005b) Planting systems and tree shape. In: Tromp J, Webster AD, Wertheim 541 SJ (eds) Fundamentals of Temperate Zone Tree Fruit Production. Backhuys Publishers, Leiden, pp 190-203

Willaume M, Lauri PÉ, Sinoquet H (2004) Light interception in apple trees influenced by canopy architecture manipulation. Trees - Structure and Function 18:705-713 


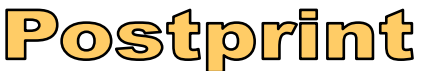

Version définitive du manuscrit publié dans / Final version of the manuscript published in : Trees, 2011, vol.26, n.1, 273-282

547 Table 1. Architectural parameters measured at D1 (i.e. start of Dysaphis plantaginea 548 multiplication phase) at branch level in original solaxe (OS) and centrifugal training (CT) 549 branches in both years

550

\begin{tabular}{|c|c|c|c|c|}
\hline \multirow[b]{2}{*}{ Architectural parameters } & \multicolumn{2}{|c|}{2007} & \multicolumn{2}{|c|}{2008} \\
\hline & OS & CT & OS & CT \\
\hline Shoot number per branch & $138.00 \pm 14.46$ & $115.75 \pm 25.24$ & $159.50 \pm 23.55$ & $272.63 \pm 45.14$ \\
\hline$\%$ long shoots ${ }^{1}$ & $30.83 \pm 3.39$ & $21.87 \pm 2.67$ & $9.98 \pm 1.83$ & $6.71 \pm 1.98$ \\
\hline$\%$ fruiting shoots & $54.92 \pm 4.88$ & $21.39 \pm 4.38$ & $8.27 \pm 4.76$ & $12.04 \pm 4.59$ \\
\hline$\%$ growing shoots & $33.28 \pm 3.91$ & $24.28 \pm 4.30$ & $25.00 \pm 1.34$ & $20.31 \pm 1.41$ \\
\hline Shoot density $^{2}$ & $78.04 \pm 3.92$ & $80.86 \pm 13.29$ & $93.60 \pm 7.86$ & $144.08 \pm 14.96$ \\
\hline
\end{tabular}

Each value is mean \pm SE on 8 infested branches

${ }^{1}$ Length categories: short, $<5 \mathrm{~cm}$; long, $\geq 5 \mathrm{~cm}$

${ }^{2}$ Total number of current-year shoots of a branch per unit of length of the main axis of this branch (number of 554 shoots. $\left.\mathrm{m}^{-1}\right)$ 


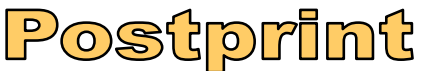

Version définitive du manuscrit publié dans / Final version of the manuscript published in : Trees, 2011, vol.26, n.1, 273-282

556 Table 2. Dysaphis plantaginea infestation at branch level in the original solaxe (OS) and 557 centrifugal training (CT) systems at D1 (i.e. start of $D$. plantaginea multiplication phase) and 558 D2 (D. plantaginea infestation peak) on apple in spring 2007 and 2008

\begin{tabular}{lcccccc}
\hline & & \multicolumn{2}{c}{ OS } & & \multicolumn{2}{c}{ CT } \\
\cline { 3 - 4 } \cline { 6 - 7 } Monitored variables & Year & D1 & D2 & & D1 & D2 \\
Infested shoots $(\%)$ & 2007 & $28.60 \pm 9.30$ & $53.88 \pm 12.04$ & & $41.02 \pm 10.83$ & $59.44 \pm 12.85$ \\
Infestation severity score & 2007 & $0.36 \pm 0.12$ & $0.77 \pm 0.20$ & & $0.50 \pm 0.13$ & $0.85 \pm 0.20$ \\
Infested shoots (\%) & 2008 & $2.77 \pm 1.15$ & $31.66 \pm 10.90$ & & $1.70 \pm 0.54$ & $25.61 \pm 7.60$ \\
Infestation severity score & 2008 & $0.04 \pm 0.02$ & $0.45 \pm 0.17$ & & $0.03 \pm 0.01$ & $0.31 \pm 0.09$ \\
\hline \multicolumn{2}{l}{ Each value is mean \pm SE on 8 infested branches } & & & &
\end{tabular}




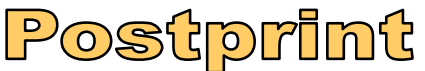

Version définitive du manuscrit publié dans / Final version of the manuscript published in : Trees, 2011, vol.26, n.1, 273-282

562 Figure 1. Topological annotation of a simplified branch taking into account branching order

563 and rank of insertion. Two shoots inserted at the same topological place (e.g. two "bourse

564 shoots" on the same flower cluster such as shoot ' 5 ' and shoot '5bis') are considered to have

565 similar branching order and one branching point between them.

$$
f_{1} *^{2} / 3
$$

567

568 Figure 2. Proportions of shoots per branching order in the original solaxe (OS) and centrifugal training (CT) branches in (a) 2007 and (b) 2008

(a)
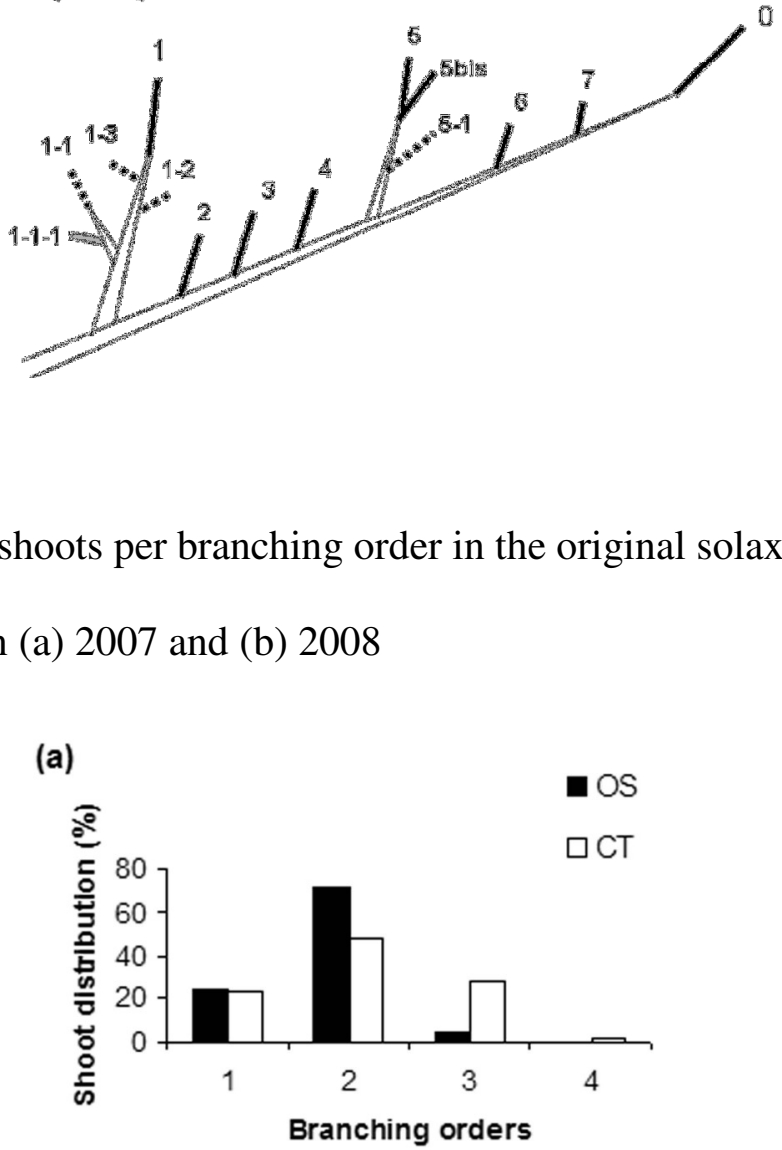

(b)

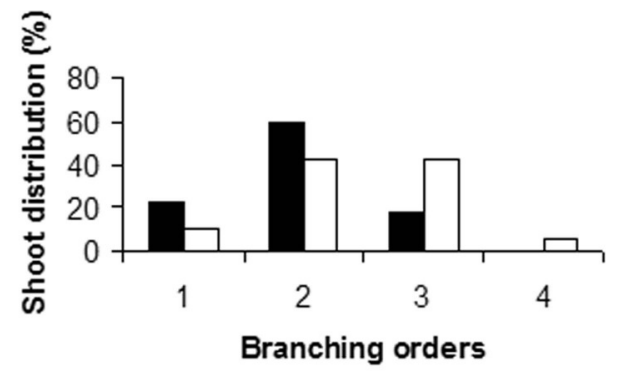




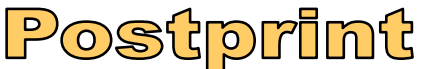

Version définitive du manuscrit publié dans / Final version of the manuscript published in : Trees, 2011, vol.26, n.1, 273-282

571 Figure 3. Infestation course between start and peak of spring Dysaphis plantaginea infestation

572 of shoots on apple in the original solaxe (OS) and centrifugal training (CT) branches in (a) $573 \quad 2007$ and (b) 2008.

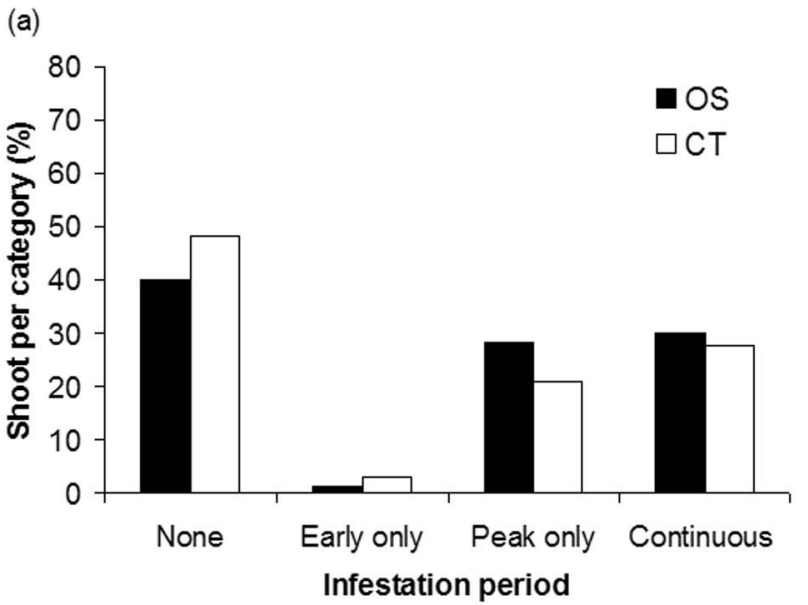

(b)

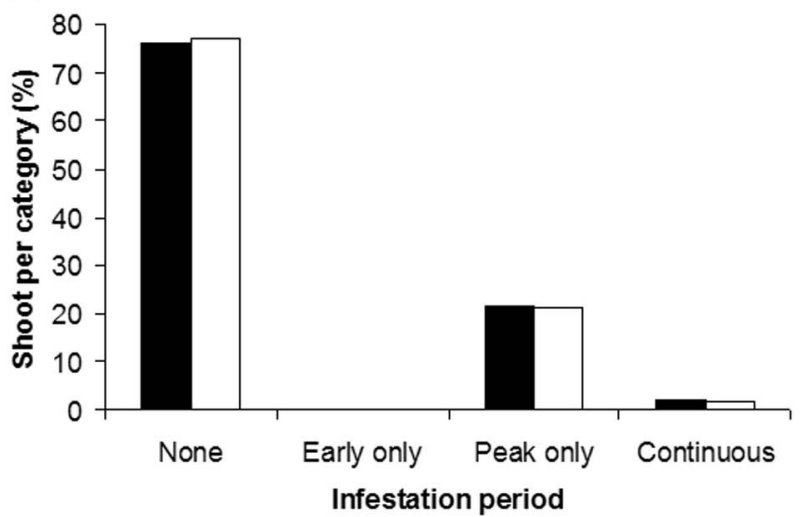




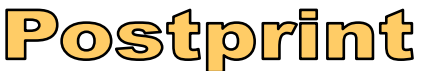

Version définitive du manuscrit publié dans / Final version of the manuscript published in: Trees, 2011, vol.26, n.1, 273-282

575

576

577

Figure 4. Relationships between Dysaphis plantaginea infestation severity of a target shoot at D2 (i.e. infestation peak) and the mean infestation severity of its nearest adjacent shoots (mean severity among 1 to 2 adjacent shoots) at D1 (start of D. plantaginea multiplication phase) on apple in years (a) 2007 and (b) 2008 in the original solaxe (OS) and centrifugal training (CT) branches. Symbols are means per severity class when three shoots or more.

When larger than symbols lines above or below symbols are standard errors. Regression lines are computed for (a) $2007 \operatorname{OS}\left(\mathrm{y}=0.5787 \mathrm{x}+0.8075, \mathrm{r}^{2}=0.7165, \mathrm{n}=6\right.$; plain line) and CT (y $=1.0804 \mathrm{x}+0.3298, \mathrm{r}^{2}=0.9898, \mathrm{n}=6$; dash line $)$ systems; (b) 2008 OS $(\mathrm{y}=0.899 \mathrm{x}+0.8116$, $\mathrm{r}^{2}=0.6717, \mathrm{n}=5$; plain line) and CT $\mathrm{y}=0.8281 \mathrm{x}+0.3829, \mathrm{r}^{2}=0.8505, \mathrm{n}=4$; dash line)
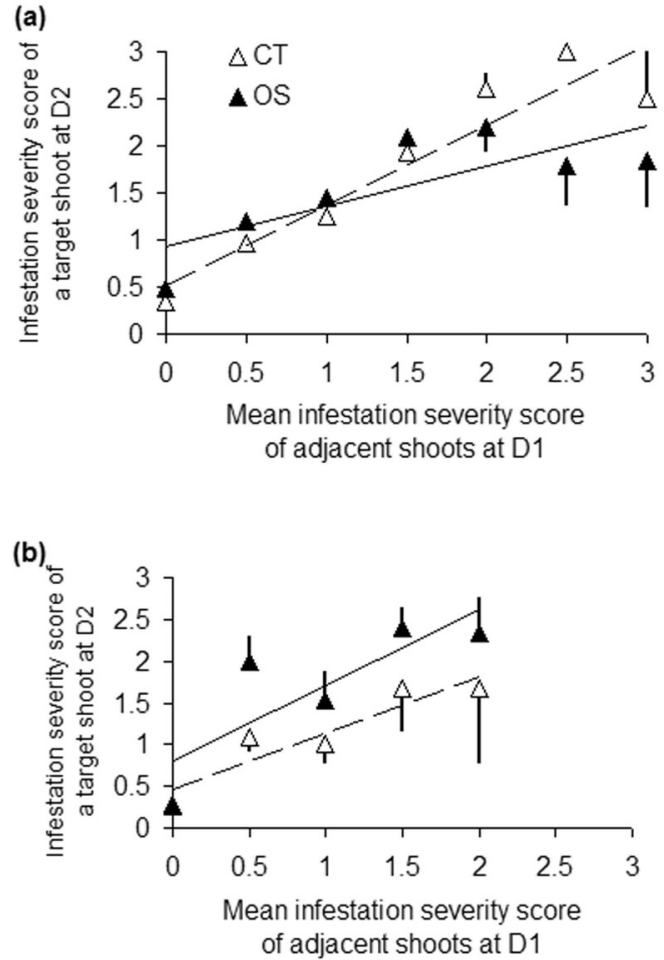


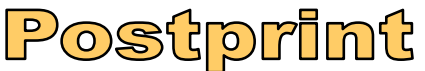

Version définitive du manuscrit publié dans / Final version of the manuscript published in : Trees, 2011, vol.26, n.1, 273-282

587 Figure 5. Relationships between Dysaphis plantaginea infestation severity of a target shoot at 588 D2 (infestation peak) and the infestation severity of its nearest proximal shoot at D1 (start of 589 D. plantaginea multiplication phase) on apple for different numbers of branching points 590 between the two shoots (2007, all shoots pooled). Symbols (means per severity class when 591 two shoots or more) and regression lines $(\mathrm{n}=4)$ are represented for 1 (dotted line), 2 (dash 592 line), 3 (plain line) and 4 (bold line) branching points. When larger than symbols lines above or below symbols are standard errors

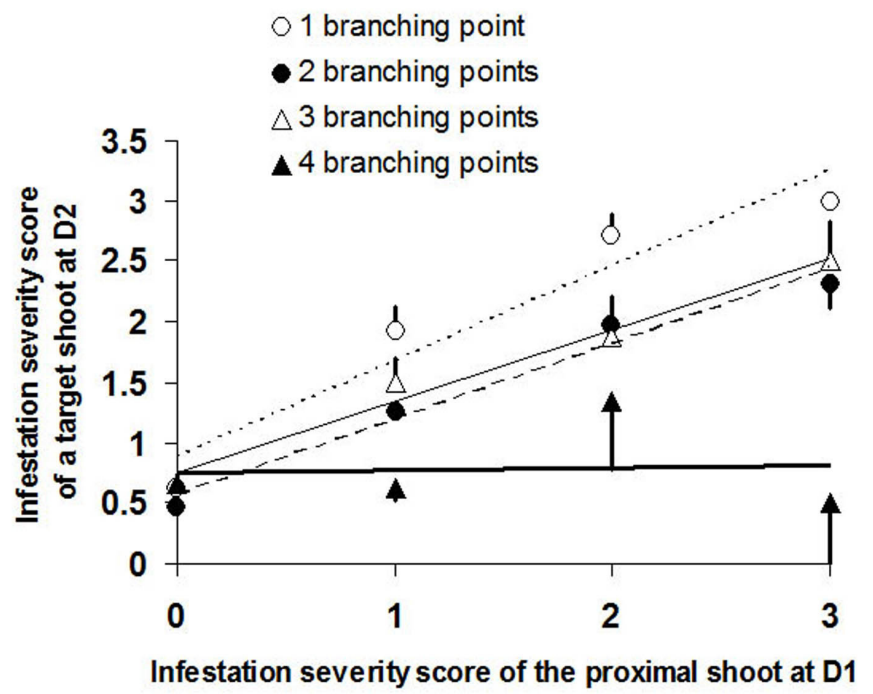

